\author{
Original Article
}

\title{
Distribution of commensal rodents in some shops of three districts in Malakand region, Pakistan
}

\author{
Distribuição de roedores comensais em algumas lojas de três distritos na região de \\ Malakand, Paquistão
}

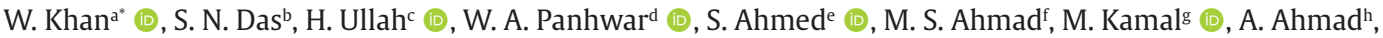 \\ M. U. Mohsin', A. Hussain ${ }^{\mathrm{j}}$ (D), G. Khaliq ${ }^{\mathrm{k}}$ (D) and I. Hussain ${ }^{1}$ (D) \\ aUniversity of Malakand, Department of Zoology, Lower Dir, Khyber Pakhtunkhwa, Pakistan \\ bSindh University Jamshoro, Department of Zoology, Hyderabad, Pakistan \\ University of Peshawar, Department of Zoology, Peshawar, Pakistan \\ dShah Abdul Latif University Khairpur, Department of Zoology, Miris, Sindh, Pakistan \\ 'Hazara University Mansehra, Department of Zoology, Mansehra, Pakistan \\ fUniversity of Swabi, Department of Zoology, Swabi, Pakistan \\ sUniversity of Karachi, Department of Zoology, Karachi, Pakistan \\ hFriedrich Schiller Universtat Jena, Department of Microbiology, Neugasse, Jena, Germany \\ iIslamia College University Peshawar, Department of Zoology, Peshawar, Pakistan \\ jUniversity of Haripur, Department of Forestry and Wildlife Management, Haripur, Pakistan \\ kLasbela University of Agriculture Water and Marine Sciences, Faculty of Agriculture, Department of Horticulture, Uthal, Baluchistan, Pakistan \\ 'University of Haripur, Department of Plant Breeding \& Genetics, Haripur, Pakistan
}

\begin{abstract}
Using wire mesh live traps distribution pattern of the Rattus rattus and Mus musculus in different shops of three districts of Malakand region, Pakistan were recorded from September 2014 to October 2015. Over all 103 rodents (Rattus rattus 86 and Mus musculus 17) were caught during in 0.04 trap success (2448 trap nights). Regression of daily captures on cumulative captures revealed an estimate of 103 rodents from all the sampled structures with an average of 3.55 rodents per shop. $R$. rattus; $83.4 \%$ of captures were numerically dominant in almost all types of shops sampled, and were significantly different than Mus musculus; $16.5 \%$ of captures. Both species were found together in some shops while they were mostly trapped from the separate shops. Male rodents outnumbered the females.
\end{abstract}

Keywords: synanthropic rodents, vertebrate pests, house rats, trap nights, Malakand-Pakistan.

\section{Resumo}

Usando o padrão de distribuição de armadilhas vivas de malha de arame do Rattus rattus e Mus musculus em diferentes lojas de três distritos da região de Malakand, o Paquistão foi registrado de setembro de 2014 a outubro de 2015. No total, 103 roedores (Rattus rattus 86 e Mus musculus 17) foram pegos durante em 0,04 armadilha de sucesso (2448 noites de armadilha). A regressão das capturas diárias em capturas cumulativas revelou uma estimativa de 103 roedores de todas as estruturas amostradas, com uma média de 3,55 roedores por loja. R. rattus; $83,4 \%$ das capturas foram numericamente dominantes em quase todos os tipos de lojas da amostra e foram significativamente diferentes do Mus musculus; $16,5 \%$ das capturas. Ambas as espécies foram encontradas juntas em algumas lojas, enquanto estavam na maior parte presas em lojas separadas. Os roedores machos eram mais numerosos do que as fêmeas.

Palavras-chave: roedores sinantrópicos, pragas de vertebrados, ratos domésticos, noites de armadilha, MalakandPaquistão.

\section{Introduction}

Rodents have persisted a key factor in the human experience and philosophy since centuries. Rodentia is composed of $1 / 4^{\text {th }}$ of the reported mammal species (Roberts, 1997). Forty three rodent species have been reported in Pakistan (Beg et al., 1979). Three species of rodents including
Rattus rattus, Rattus norvegicus and Mus musculus have been considered synanthropic importance (Aplin et al., 2003; Cavia et al., 2009). R.rattus is cosmopolitan in distribution and originally it is South East Asian murid (Meehan, 1984). In Pakistan R. rattus is an indoor species of rodents

*e-mail: walikhan.pk@gmail.com

Received: May 27, 2020 - Accepted: July 27, 2020

This is an Open Access article distributed under the terms of the Creative Commons Attribution License, which permits unrestricted use, distribution, and reproduction in any medium, provided the original work is properly cited. 
(Roberts, 1997). A large number of $R$. rattus have been observed in grain markets of Rawalpindi, Punjab, Pakistan (Ahmad et al., 1995), however they were not sure on the presence of $R$. norvegicus in the study area. It has been estimated that on an average, a grain shop harbored up to 40 rats resulted an estimation 4000 metric tons annul loss of grain in Punjab, Pakistan.

Synanthrops nature of rats and mice has a key role in transmitting infections of great zoonotic importance (Yasuraoka et al., 1996). Over 60 known diseases have been reported to be transferred from rodents to humans and the number is still increasing day by day as more and more research on zoonosis (Khatoon et al., 2004). Owing to their importance as public health hazard, rodents borne diseases like rat bite fever, murine typhus, leptospirosis, toxoplasmosis, trichinosis, salmonellosis and the plague have accounted for the death of more than 20 million people (WHO, 2007). A large part of human population in Pakistan has suffered from high exposure to rodent attacks as they live in squared and slum areas.

Present study was aimed to provide information regarding pattern of distribution of commensal rodents in different shops in three districts of Malakand region, where studies on dispersal pattern and abundance of rodent pests are lacking. Such studies will help policy makers to plan for controlling of rodent pests in agricultural ecosystem and in stored products.

\section{Materials and Methods}

\subsection{Study area}

This study was conducted in different shops of different areas of district Malakand, district Lower Dir and district Swat. They lies $34^{\circ} 22^{\prime}$ and $35^{\circ} 50^{\prime}$ North and $71^{\circ} 02^{\prime}$ and $72^{\circ} 30^{\prime}$ East and $34^{\circ} 34^{\circ}$ to $35^{\circ} 55^{\circ}$ North and $72^{\circ} 08^{\circ}$ to $72^{\circ} 50^{\circ}$ East which are situated towards North of the province of Khyber Pakhtunkhwa. The current study was carried out from September 2014 to September 2015.

The climate of the area is dry. It has hot summer and cold winters. The annual average maximum and minimum temperatures are about $29{ }^{\circ} \mathrm{C}$ and $12{ }^{\circ} \mathrm{C}$ respectively. The annual rainfall varies between $600 \mathrm{~mm}$ to $1100 \mathrm{~mm}$. The rainfall is erratic, mostly received in monsoon that is July - August. Snowfall is much rare and seldom occurs on the tops of some mountains, which is again followed by immediate melting. Frost commonly occurs and starts by the mid of the November. The overall weather is extreme. Agriculture is the prime most and live - stock is second in number for living.

\subsection{Trapping of rodents}

A total of 179 locally available commercial wire mesh live traps of medium size were used for rodents capturing. During capturing the rodents each of the traps were baited with oily bread, which are gamely attractive by the rodent pest. A total of 3 to 4 shops were selected randomly for indoor trapping at each locality. The number of traps allocated at each shops ranges 4-24 traps for 3 consecutive days in the evening and picked up in the morning. Traps were set where signs of rodent movements were recorded particularly against the wall. Month wise trapping was carried out in each sampled locality.

\subsection{Trap success}

Population abundance of the rats trapped were calculated by applying the following Formula 1 :

$\%$ trap success (abundance) $=$ Number of rodent trapped / Number of trap nights x100

\subsection{Anesthetization of the rodents}

All the live captured specimens of rodents were anaesthetized with chloroform and the following information were reported.

\subsection{Visualizing the age by}

\subsubsection{Weight of the body}

Each of the rodent specimens were weighed by using the Precisa balance model No.18220 Switzerland.

\subsubsection{Rats and mice specimen age}

On the bases of body weight rats were divided in to two age groups: Juvenile: < 55 grams for males and females, adults: < 200 grams for males and < 100 grams for females.

\subsubsection{Rats and mice specimen sex}

Based on inspection of sexual organs via naked eyes, the sex was determined as: male; when the ano-genital distance was measured usually greater and in female; when the ano-genital distance was measured usually less than male.

\section{Results}

A total of 103 rodents were captured including 83.4\% (Rattus rattus $=86$ ) and $16.5 \%$ (Mus musculus=17). The majority of rats as well as mice were trapped at Swat district and less were trapped at lower Dir district (Chakdara). House rats (Rattus rattus) were trapped at all sites except dry fruit shops while house mice (Mus musculus) were not trapped only at sweet shops and fruit shops. Rats were usually trapped during all the seasons of the year except spring and summer in Malakand and Lower Dir district (Chakdara) while mice were trapped only during autumn and winter seasons (Table 1).

\subsection{Abundance of commensal rodents}

The population abundance indices of Rattus rattus ( $n=86)$ was greater than Mus musculus ( $n=17)$ and was statistically significant ( $P$ value 0.0007 with $95 \%$ confidence of interval 5.089 to 14.63 ) among habitats. R.rattus was the species that numerically predominant in every habitats while $M$. musculus were also trapped in some of the sampled habitat, including grocery shops, bakeries and sweet shops, grain godowns, rice godowns, 


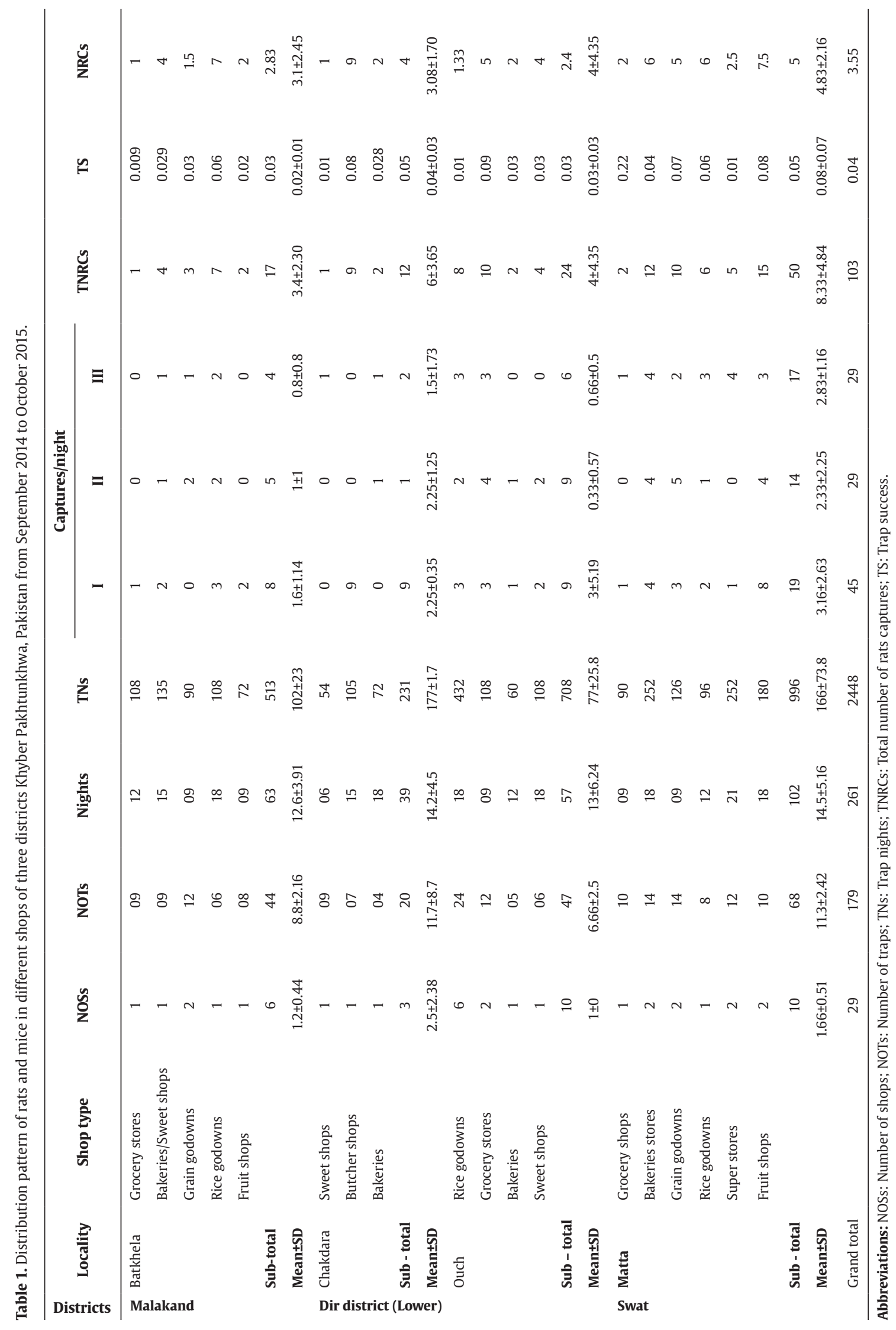


fruit shops, super stores and Butcher shops. M. musculus were usually considered in-house species, where rats are not in abundance. $R$. rattus came to be the most abundant in rice godowns in Batkhela-Malakand, in Butcher shops in Chakdara Lower Dir, in rice godowns in Ouch-Lower Dir and in fruit shops in Matta-Swat. Population density of rats and mice in three districts was not statistically significant (P value 0.0628 with $95 \%$ confidence interval -1.967 to 47.97 ) (Figure 1 ).

\subsection{Sex ratio and seasons}

Males were trapped more $(n=62)$ than females $(n=41)$ in both the species but not statistically different ( $\mathrm{P}$ value 0.5375 ; with $95 \%$ confidence interval range -14.40 to 24.90 ). Sex ratio: 1.3:1.0 and 3.25:1 male and female in rats and mice were regarded in all the shops studied.
Present data reveals the season wise population abundance for rats and mice as: 7,0; 6,0; 42,7; 31,10 were trapped during autumn, winter, spring and summer respectively but not statistically different (P value 0.1130 with $95 \%$ confidence interval -5.506 to 40.01 ). Locality wise the population abundance of the rodents trapped was: 17 (16.5\%), 36 (34.9\%) and 50(48.5) in Malakand, Lower Dir and Swat districts. The majority of the rats were trapped at the Swat district during autumn while no rat was trapped during spring and summer at districts Malaknd and Lower Dir except 2 male rats were trapped during spring in Ouch-Lower Dir district. Same number of the mice were trapped during winter in Malaknd, Ouchlower Dir district and Swat while no mouse was trapped during spring and summer at all the localities. Population density of rats and mice in different seasons of the year was not statistically significant (P value 0.0628 with $95 \%$ confidence interval range -1.967 to 47.97 ) (Figure 2 ).

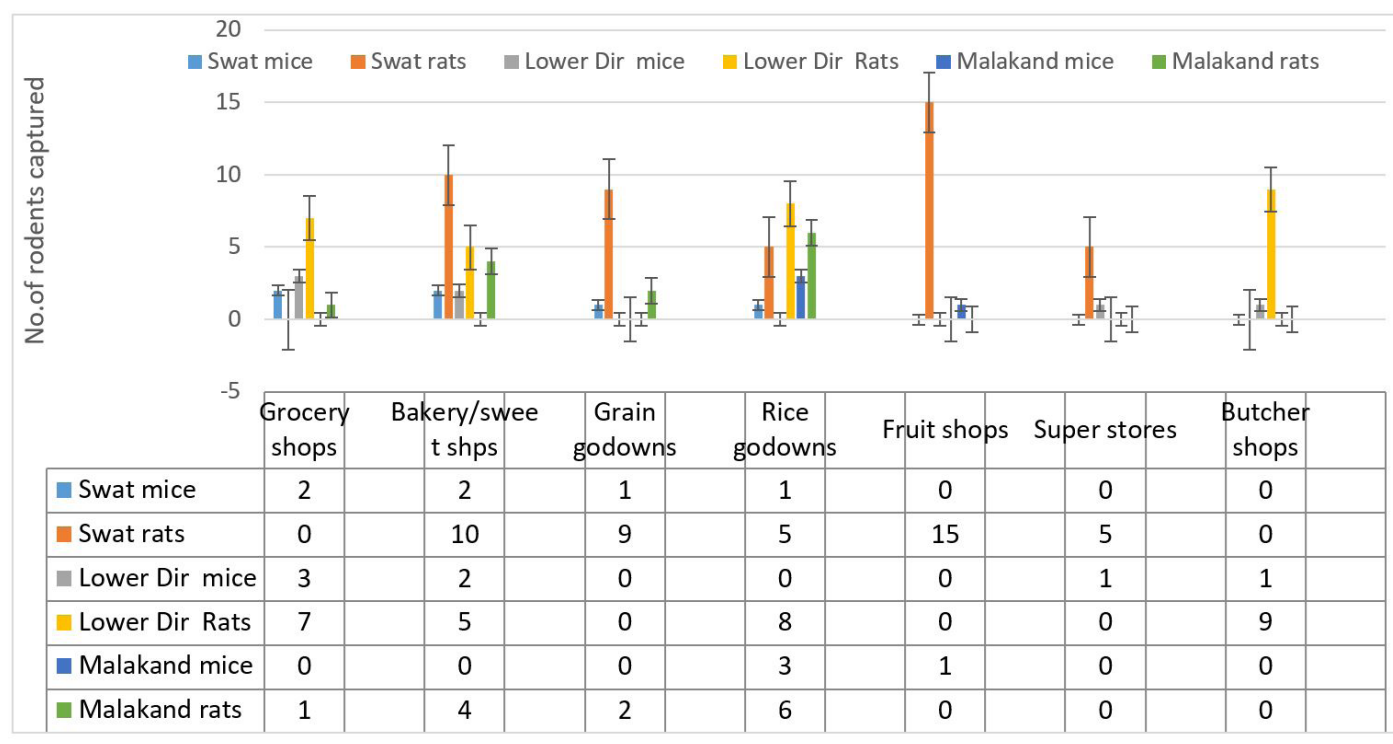

Figure 1. Distribution of rodents in different shops of 3 districts (Swat, Lower Dir and Malakand) of Khyber Pakhtunkhwa, Pakistan.

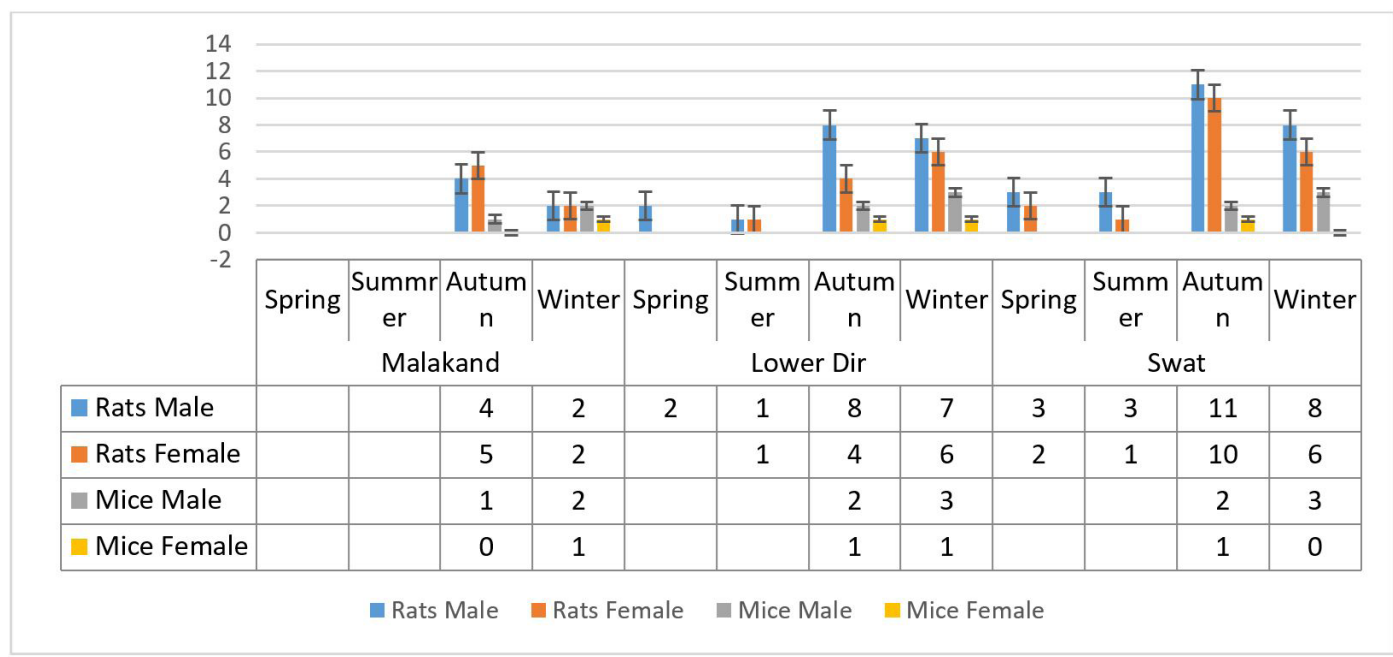

Figure 2.Variation in population dynamics of rodents (Rattus rattus and Mus musculus) in different seasons of the year. 


\section{Discussion}

Zoonotic infections have a number of linkage between host and parasite. Close interaction of rodent with humans creates a leading threat to human life. Commensal rodents are the transmitting agents of a large number of zoonotic pathogens to humans and their live-stock through urine, feces, aerosols and ectoparasites. Rodents make the environment suitable for maintaining the population become active (Belmain et al., 2002; Pocock et al., 2004). The richness of $R$. rattus in the study area could be due to the availability of food and place, which may therefore attract these murids. Rattus rattus was the richest species in the sampling area, supporting the findings of Castillo et al. (2003), Hancock (2008), Gomez et al. (2009), Sidorov and Putin (2010) and Mushtaq et al. (2014). The overlapping of the R.rattus species in grocery shops and in grain godowns $44.8 \%$ ( $13 / 29$ shops have observed, while in all the cases, $R$. rattus were recorded as $83.4 \%$ (86/103). $R$. rattus had a higher relative proportion than M. musculus 16.5\% (17/103) Figures 1 and 2 .

Rodents have an enormous economic impact on stored grain in developing countries. It has been estimated that the annual loss of food due to rodents is about $11 \mathrm{~kg} /$ person. This value is equal to the combined gross national product of $25 \mathrm{~kg} /$ person of the poorest nations (Gwinner et al., 1996).

Impact of different species of Rattus and Mus on storage facilities frequently has been documented by (Buckle and Smith 1994; Hofp et al., 1976) in various countries as: up to $10 \%$ in Laos and Malaysia (Muda, 1986) $5 \%$ in Thailand, 5\% in Phillipines (Caliboso et al., 1986), 20\% in Korea (Sidik et al., 1986).

Regarding sex ratio of the specimens' males 1.3 and 1 were more captured than females 1.0 and 1 in rats and mice respectively in the current study. Sex ratio reflects the capability of the species respond to natural selection (Wu et al., 2006). The availability of food in abundance favor the 1:1 sex ratio in polygamous species (Wright et al., 1988). Current research favor this phenomenon in some extent for R. rattus, however in M. musculus the sex ratio is different from 1:1 with higher recorded capture of males. Kunimoto et al. (2002) recorded 2.1: 1 male-female ratio in population of M. musculus in Peru while Gomez et al. (2009) reported variation in the sex ratio in the same species in different areas and seasons in Argentina. Occupying areas in search of food by the females with which to mate with males but are commonly resisted by dominant males, which leads to an increased possibility of captures. During reproduction the females do not go away from their nests and their areas of activity becomes limited than males as they usually busy in nursing their young's particularly in pregnancy and lactation (Hernández-Betancourt et al., 2003; Frynta et al., 2005). Further, wild populations have a clear reproductive periodicity (Singleton et al., 2001), while commensal rodents' exhibits no such reproductive seasonality. The reproductive seasonality in rodents may due to the availability of optimal conditions for reproduction (Sidorov and Putin, 2010) and the aggressiveness of the adults lead to make low rate of young individuals of both species (Drickamer et al., 1999) hence the rodents takes very short time to attain their sexual maturity. All of the trapped rats and mice were adults while no sub-adults or juveniles were found to be trapped, which an accordance to the work cited above is.

According to Brooks et al. (1994) and Mushtaq et al. (2014) no rat proof mechanism was seen. A similar situation was observed during the present investigation; most of the shops were found heavily loaded with the food items, which may be provide excellent habitat for placing the rodents. The stored food materials and the deposition of waste may provide supreme opportunity to increase the number of rodents. This situation may lead the lack of sanitation, contamination of food items by the rodent excreta which may be easily transferred to human on consumption. Same studies have also been documented by Childs et al. (1998), Lambropoulos et al. (1999) and Pocock et al. (2004). The rodent infestation represent in high health risk. Presence of rodents near human settlements indicate zoonotic disease transmission (Castillo et al., 2003).

Current research is the first attempt to scrutinize populations of commensal rodents in different study structures of three districts of Malakand region, which picture the possible health hazards to inhabitants of the area. This study yield evidence for knowing the risk due to these rodents to the public health. Further research is needed for the effective dealings to reduce rodent populations.

\section{Acknowledgments}

We thank the shopkeepers for their support to keep the traps in their shops and all those who facilitated the work and for their participation.

\section{References}

AHMAD, E., HUSSAIN, I. and BROOKS, J.E., 1995. Losses of stored foods due to rats at grain markets in Pakistan. International Biodeterioration E Biodegradation, vol. 36, no. 1-2, pp. 125-133. http://dx.doi.org/10.1016/0964-8305(95)00087-9.

APLIN, K.P., BROWN, P.R., JACOB, J., KREBS, C.J. and SINGLETON, G.R., 2003. Field methods for rodent studies in Asia and the Indo-Pacific. Australia: Australian Centre for International Agricultural Research, pp. 223.

BEG, M.A., KHAN, A.A. and BEGUM, F., 1979. Rodent problem in sugarcane fields of central Punjab. Pakistan Journal of Agricultural Sciences, vol. 16, no. 1-2, pp. 123-129.

BELMAIN, S.R., MEYER, A.N., PENICELA, L. and XAVIER, R., 2002. Population management of rodent pests through intensive trapping inside rural households in Mozambique. In: Proceedings of the $4^{\text {th }}$ International Conference on Urban Pests (ICUP), 2002, Charleston. Charleston: ICUP, pp. 421-428.

BROOKS, J.E., AHMED, E. and HUSSAIN, I., 1994. Reproductive biology and population structure of Rattus rattus in Rawalpindi, Pakistan. Zeitschrift fur Saugetierkunde, vol. 59, pp. 209-217.

BUCKLE, A.L. and SMITH, R.H., 1994. Rodent pests and their control. Wallingford: CAB International.

CALIBOSO, F.M., SAYABOC, P.D. and AMORANTO, M.R., 1986. Pests problem and the use of pesticides in grain storage in the Phillipines. In: ACIAR Proceedings Series, Australian Centre for 
International Agricultural Research, 1986, Australia. Wallingford: CAB International, pp. 17-29.

CASTILLO, E., PRIOTTO, J., AMBROSIO, A.M., PROVENSAL, M.C., PINI, N., MORALES, M.A., STEINMANN, A. and POLOP, J.J., 2003. Commensal and wild rodents in an urban area of Argentina. International Biodeterioration \& Biodegradation, vol. 52, no. 3, pp. 135-141. http://dx.doi.org/10.1016/S0964-8305(03)00033-7.

CAVIA, R., CUETO, G.R. and SUÁREZ, O.V., 2009. Changes in rodent communities according to landscape structure in an urban ecosystem. Landscape and Urban Planning, vol. 90, no. 1-2, pp. 11-19. http://dx.doi.org/10.1016/j.landurbplan.2008.10.017.

CHILDS, J.E., MCLAFFERTY, S.L., SADEK, R., MILLER, G.L., KHAN, A.S., DUPREE, E.R., ADVANI, R. and GLASS, G.E., 1998. Epidemiology of rodent bites and prediction of rat infestation in New York City. American Journal of Epidemiology, vol. 148, no. 1, pp. 78-87. http:// dx.doi.org/10.1093/oxfordjournals.aje.a009563. PMid:9663407.

DRICKAMER, L., FELDHAMER, G., MIKESIC, D. and HOLMES, C., 1999. Trap response heterogeneity of house mice (Mus musculus) in outdoor enclosures. Journal of Mammalogy, vol. 80, no. 2, pp. 410-420. http://dx.doi.org/10.2307/1383289.

FRYNTA, D., SLÁBOVÁ, M., VÁCHOVÁ, H., VOLFOVÁ, R. and MUNCLINGER, P., 2005. Aggression and commensalism in house mouse: a comparative study across Europe and the Near East. Aggressive Behavior, vol. 31, no. 3, pp. 283-293. http://dx.doi. org/10.1002/ab.15555.

GOMEZ, M.D., PROVENSAL, C. and POLOP, J., 2009. Microhabitat use by the house mouse Mus musculus in an urban area. Acta Theriologica, vol. 54, no. 2, pp. 183-192. http://dx.doi. org/10.1007/BF03193174.

GWINNER, J., HARNISCH, R. and MUSK, O., 1996. Manual of the prevention of the post-harvest grain losses. Berlin: Deutsche Gesellschaft.

HANCOCK, B., 2008. The influence of ship rats (Rattus rattus) on the habitat preferences of the house mouse (Mus musculus). Wellington: Victoria University of Wellington, 117 p. Master of Science in Ecology and Biodiversity.

HERNÁNDEZ -BETANCOURT, S., LÓPEZ, W.R., CIMÉ, P.J. and MEDINA, P.S., 2003. Área de actividad, movimiento y organización social de Heteromys gaumeri Allen y Chapman, 1897 (Rodentia: Heteromydae) en una selva mediana subcaducifolia de Yucatán, México. Acta Zoológica Mexicana, vol. 90, pp. 77-91.

HOFP, H.S., MORLEY, G.E.J., HUMPHRIES, J.R.O., 1976. Rodent damage to growing crops and to farm and village storage in tropical and sub-tropical regions. London: Centre for overseas Pest research and Tropical product institute.

KHATOON, N., BILQEES, F.M., SHAHWAR, D. and RIZWANA, A.G., 2004. Histopathological alterations associated with Syhacia spp. (Nematode) in the intestine of Nesokia indica. Turkish Journal of Zoology, vol. 28, pp. 345-351.

KUNIMOTO, C., DE LA CRUZ, C., ARANA, M. and RAMÍREZ, O.E., 2002. Observations sobre la ecología poblacional Del ratón doméstico en Lachay, Perú. Boletín del Instituto Francés de Estudios Andinos, vol. 31, no. 31 (2), pp. 323-328. http://dx.doi.org/10.4000/bifea.6753.
LAMBROPOULOS, A.S., FINE, J.B., PERBECK, B., TORRES, D., GLASS, G.D., MCHUGH, P. and DORSEY, E.A., 1999. Rodent control in urban areas. An interdisciplinary approach. Environmental Health, vol. 61, pp. 12-17.

MEEHAN, A.P., 1984. Rats and mice, their biology and control. East Grinstead, Sussex, UK: Rentokil.

MUDA, A., 1986. Pest problem and the use of pesticides in grain storage in Malaysia. In: ACIAR Proceedings Series, Australian Centre for International Agricultural Research, 1986, Australia. Wallingford: CAB International, vol. 14, pp. 11-16

MUSHTAQ M., KAYANI, A.R., NADEEM, M.S. and BEG, M.A., 2014. Distribution pattern of commensal rodents in shops of urban Rawalpindi, Pakistan. Pakistan Journal of Zoology, vol. 46, no. 6, pp. 1585-1589.

POCOCK, M.J.O., SEARLE, J.B. and WHITE, P.C.L., 2004. Adaptations of animals to commensal habitats: population dynamics of house mice, Mus musculus domesticus on farms. Journal of Animal Ecology, vol. 73, no. 5, pp. 878-888. http://dx.doi. org/10.1111/j.0021-8790.2004.00863.x.

ROBERTS, T.J., 1997. Mammals of Pakistan. Karachi: Oxford University Press, pp. 525

SIDIK, M., HALI, H. and PRANTA, R.I., 1986. Pest problems and the use of pesticides in grain storage in Indonesia. In: ACIAR Proceedings Series, Australian Centre for International Agricultural Research, 1986, Australia. Wallingford: CAB International, vol. 14, pp. 37-43.

SIDOROV, G.N. and PUTIN, A.V., 2010. The house mouse (Mus musculus L) in Omsk educational institutions: seasonal migration, abundance, reproduction, distribution, foraging, and associated damage. Contemporary Problems of Ecology, vol. 3, no. 5, pp. 819-825. http://dx.doi.org/10.1134/S1995425510050164.

SINGLETON, G.R., HINDS, L.A., LAWSON, M.A. and PECH, R.P., 2001. Strategies for management of rodents: prospects for fertility control using immunocontraceptive vaccines. In: D.P. COWAN and C.J. FEARE, eds. Advances in vertebrate pest management II. Fürth: Filander-Verlag, pp. 301-318

WORLD HEALTH ORGANIZATION - WHO, 2007. Report of the $5^{\text {th }}$ Consultative Meeting on Leishmania. Geneva: WHO. pp. 20-22. Addis Ababa, Ethiopia.

WRIGHT, S.Y., CRAWFORD, C. and ANDERSON, J.L., 1988. Allocation of reproductive effect in Mus domesticus: response of offspring sex ratio and quality to social density and food availability. Behavioral Ecology and Sociobiology, vol. 23, no. 6, pp. 357-366. http://dx.doi.org/10.1007/BF00303709.

WU, S.Y., LIN, Y.K. and YU, H.T., 2006. Population ecology of the Southeast Asian house mouse (Muridae: mus musculus castaneus) inhabiting rice granaries in Taiwan. Zoological Studies (Taipei, Taiwan), vol. 45, pp. 467-474.

YASURAOKA, K.B.L., BLAS, H., MATSUDA, Y., LRIE, N., NIHEI, H., OHMAE, H., YOKOI, R., HAMBRE, R., PANGILINAN, C., AUTENTICO, C. and TANAKA, H., 1996. Approaches to the elimination of Schistosomiasis on Bohol Island, Philippines. Japanese Journal of Parasitology, vol. 45, no. 5, pp. 391-399. 